\title{
FIELD EROSION BY WIND AS INDICATED BY FLUCTUATIONS IN THE ASH CONTENT OF SPHAGNUM PEAT
}

\author{
IRMELI VUORELA
}

\begin{abstract}
VUORELA, IRMELI, 1983: Field erosion by wind as indicated by fluctuations in the ash content of Sphagnum peat. Bull. Geol. Soc. Finland 55. 1, 25-33.

The ash content curves for three Sphagnum peat profiles were correlated with those for Cerealia and the natural indicators of bare mineral soil. The fluctuations in the ash values seem to indicate erosion of fields by wind as a result of tilling and other activities in cultivated fields.

The increase in these values in the uppermost samples is an even better indicator of improvements in agriculture than are the curves for Cerealia and weeds, which decrease together with the small pollen production of the recently dominant crop species and advances made in agricultural technology.

The local pre-agrarian cultural phases revealed by the $\mathrm{C}^{14}$ datings and the tree pollen data cannot be documented by the ash content values of the Carex peat profiles.
\end{abstract}

Key words: Field erosion, ash content, Sphagnum peat, aeolian, pollen, ignition residues.

Irmeli Vuorela: Department of Geology, Division of Geology and Palaeontology, University of Helsinki, P.O. Box 115, SF-00171 Helsinki 17, Finland.

\section{Introduction}

The first application of loss-on-ignition values of limnic sediments in Finland (Alhonen 1967) was connected with the research of natural lake sedimentation. The method became later (Tolonen et al. 1975, 1976) an established part of the investigation aimed at searching for indications of prehistoric agriculture. Until recently, however, the term "field erosion" referred only to lake sediments affected by larger amounts of mineral matter being washed into the basin.

Kramm (1978) has made a detailed microscopical analysis correlating the frequencies of airborn inorganic dust particles and Rumex pollen in two peat profiles from NW Germany. The results show that these components correlate particularly in the upper part of the profile, indicating human activity. 
Field erosion by wind has also been documented in two Sphagnum peat profiles from southern Finland (Vuorela 1975, Nunez \& Vuorela 1979), where the ash content values of the moss samples increase along with the pollen indicators of human activity. The interpretation from Loimansuo was confirmed by submitting the ignition residues to electron microscopy and by analysing them at certain levels (see Vuorela 1975, fig. 17). Not less than $72 \%$ of the detrital inorganic grains were quartz.

Information on the ash distributions in raised bogs has been reported from several countries (e.g. Driessen et al. 1979), but the sampling intervals of the profiles are usually as great as $0.5-1 \mathrm{~m}$. Even so, this component tends to increase towards the surface layers.

The ash content values of Finnish bog mosses have been published in connection with the inventory of peat resources for industrial use (Raikamo 1982). The results are, however, based on very rough measurements of layers $40-100 \mathrm{~cm}$ thick of ombrogenous Sphagnum (S) or Eriophorum-Sphagnum (ErS) peat. The ash contents for Sphagnum vary within the range $1.0-4.2$, the mean value being 1.9. For ErS the corresponding values are $0.8-9$ and 2.4 , two exceptionally high values (7 and 9) occurring in the surface layers.

With reference to the studies mentioned above and to the results obtained from further investigation, the present paper aims to discuss the indicative value of the ash content fluctuations in Sphagnum peat profiles. To do this, detailed curves for the ignition residues (ash content \%) of three profiles of Sphagnum peat have been correlated with corresponding Cerealia pollen curves and with total curves for the natural indicators of open mineral soil, Artemisia, Chenopodiaceae, Rumex and Plantago (cf. Iversen 1941, Fries 1951), which may be assumed to originate from the same areas.
The bogs discussed are Retulansuo, Hattula (Nunez \& Vuorela 1979), Lemunsuo, Perniö (Vuorela unpubl.) and Loimansuo, Huittinen (Vuorela 1975). Additional data on minerogenous Carex-forest peat derive from profiles in Vohtenkellarinsuo, Paimio (Glückert 1976, 1977, Vuorela 1983) and Perkiö, Hauho (Vuorela 1982).

All the $\mathrm{C}^{\mathbf{1 4}}$ determinations were performed at the Radiocarbon Dating Laboratory, Helsinki. Two $\mathrm{C}^{\mathbf{1 4}}$ datings from Lemunsuo, $600 \pm 90(\mathrm{Hel}-1640)$ at the start of permanent field cultivation and $880 \pm 100$ B.P. (Hel1641) at the start of an older cultivation phase, have not been published previously.

\section{Material and methods}

The material from Retulansuo, Lemunsuo and Loimansuo is Sphagnum peat with sporadic Eriophorum remains. The slight fluctuations recorded in the grade of humification of these cores have not been described as the relative pollen frequencies do not depend on this factor.

The material from Vohtenkellarinsuo and Perkiö is mainly Carex-forest peat with Sphagnum peat in the uppermost layers only.

When sampling the material for the losson-ignition analysis, we avoided the remains of wood fragments and Eriophorum leaves. The agricultural period corresponds to the Sphagnum peat layers in all these samples.

The samples were ashed at $550^{\circ} \mathrm{C}(2.5 \mathrm{~h})$. To avoid fluctuation due to samples too small in size, the amount of dry material used for the determination was kept to about $1 \mathrm{~g}$ in the new determinations. Samples were weighed to an accuracy of $0.0001 \mathrm{~g}$. The samples were taken every $2.5 \mathrm{~cm}$ or $5 \mathrm{~cm}$.

The pollen data of indicator species were recorded as rates per one thousand arboreal pollen at each level. 


\section{Results}

The ash content of Sphagnum peat is held to be »less than $5 \%$ \% (Kivinen \& Pakarinen 1981: 12); in Retulansuo (Fig. 1) the mean value for the inter-agrarian periods is even less than $1 \%$ (cf. Driessen et al. 1979). This should be roughly the value for clean Sphagnum peat, as the bog is located on an isolated island (Retula) lacking sandy or silty deposits. Most of the till in the vicinity of the bog has been washed by the lake Vanajavesi (Auer 1924; Nunez \& Vuorela 1979). The ash contents that reach $4-5 \%$ in the surface samples must therefore have been affected by secondary mineral matter.

In Retulansuo the fluctuations in these values are very small, $0.5-3 \%$, throughout the period of prehistoric and historic agriculture, partly because of the relatively high growing rate of ombrogenous Sphagnum peat (Aaby \& Tauber 1974, Moore \& Bellamy 1974) and partly because of the soil type peat and clay - cleared for agriculture on Retula (Nunez \& Vuorela 1979). The airborn material from the early fields consisted mostly of organic peat dust, which cannot be separated from the original material at the sampling site. From the $20 \mathrm{~cm}$ level upwards, the more developed agriculture has a more marked, but still modest, influence on the ash content, which now reaches $3 \%$. The indicators of bare mineral soil show a particularly distinct increase at the $17.5 \mathrm{~cm}$ level, thus indicating the clearing phase of the adjacent fields.

Right at the surface the ash content reaches $5 \%$; hence, the figures reported by Kivinen and Pakarinen (1981) refer to the surface layers of Sphagnum peat. Even if the increase in airborn mineral material in Retulansuo is no higher than 1 to $5 \%$, it correlates nicely with the frequency of pollen indicators of human activity, not least with Cerealia pollen.
The clear decrease in the indicator pollen in the topmost samples will be discussed later.

Even in the pre-agrarian deposits of Loimansuo (Fig. 1), the variations in ash content remain below $1 \%$. The indication of early agriculture shows up clearly in the two curves at the $160-175 \mathrm{~cm}$ level corresponding to the Iron Age, when the ash content rose to $3 \%$. Later, advances in field cultivation and permanent settlement are reflected in an ash peak at the $40 \mathrm{~cm}$ level together with a rise in the Cerealia curve and a steadily increasing ash content from the $50 \mathrm{~cm}$ level towards the surface. This increase, to c. $5 \%$, corresponds to that of Cerealia and indicator pollen and is very similar to the values obtained from Retulansuo.

The ignition residues from the $10-15 \mathrm{~cm}$ level were submitted to electron microscopy. Besides the mineral matter mentioned above, remains of the microflora of the Sphagnum peat were recorded (Figs. 2 and 3; cf. Nieminen 1979). The amount of this kind of material is, however, insufficient to cause the high ash values of these levels.

In the peat profile from Lemunsuo (Fig. 1), too, the fluctuations in the ash content curve correlate nicely with those for Cerealia. The mean value for the ash content is higher than that of Retulansuo or Loimansuo and may reflect either a shorter distance between the bog and the action area of the settlement or the different types of soil tilled, especially as the rate of peat accumulation is approximately the same in Loimansuo and Lemunsuo. All the curves show enhanced values at the $90-97 \mathrm{~cm}, 65-72.5 \mathrm{~cm}$ and $40-50 \mathrm{~cm}$ levels, the oldest phase dating back to the days of the Vikings or the Crusades. A distinct increase can be dated to $600 \pm 90$ B.P. (Hel-1640) at the $50 \mathrm{~cm}$ level.

In the Lemunsuo profile the ash content of Sphagnum peat is around 2-3\%, except right at the surface where it fluctuates between 5 and 7 . 
RETULANSUO, Hattula

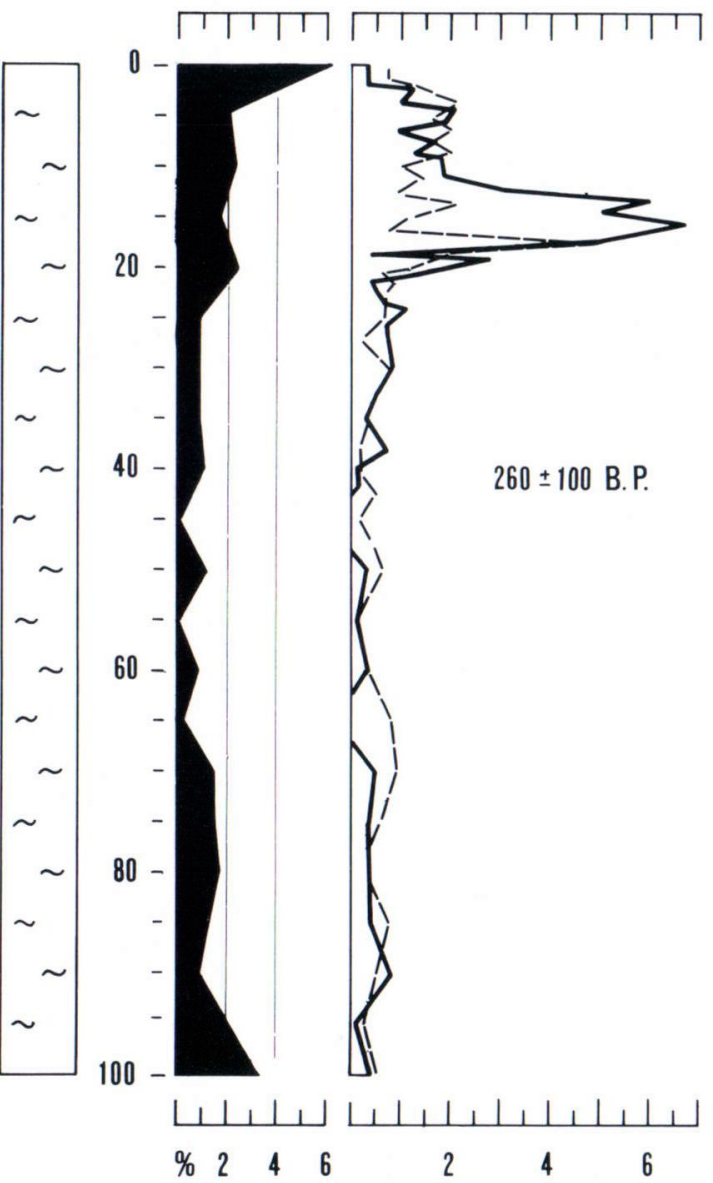

Ash-content Cerealia \%o AP+NAP
LEMUNSUO A, Perniö

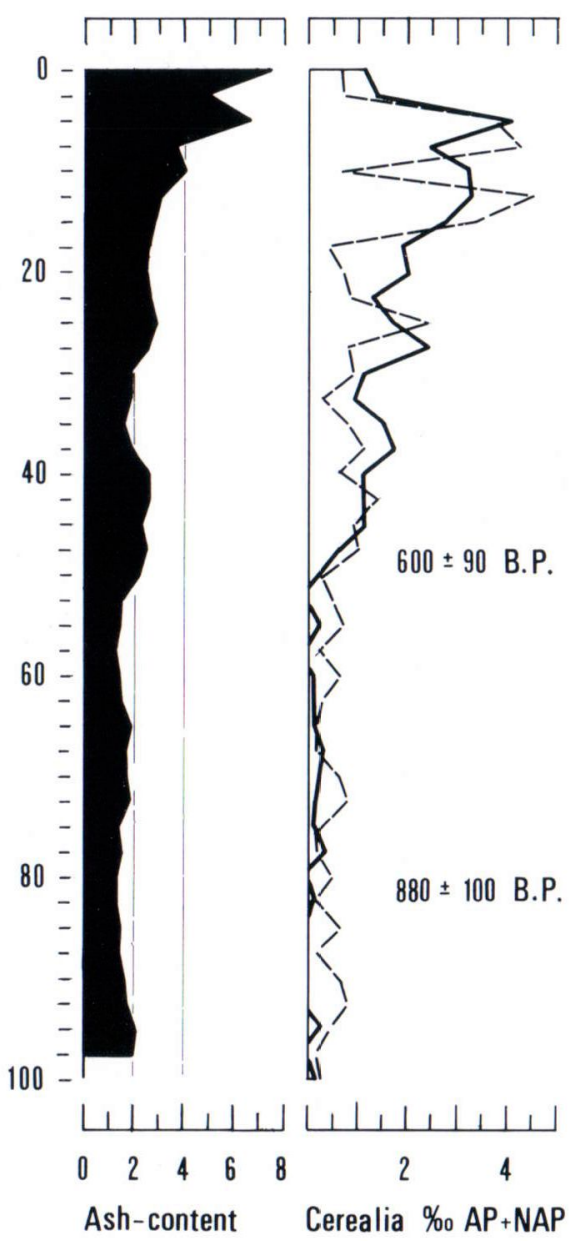

LOIMANSUO, Huittinen

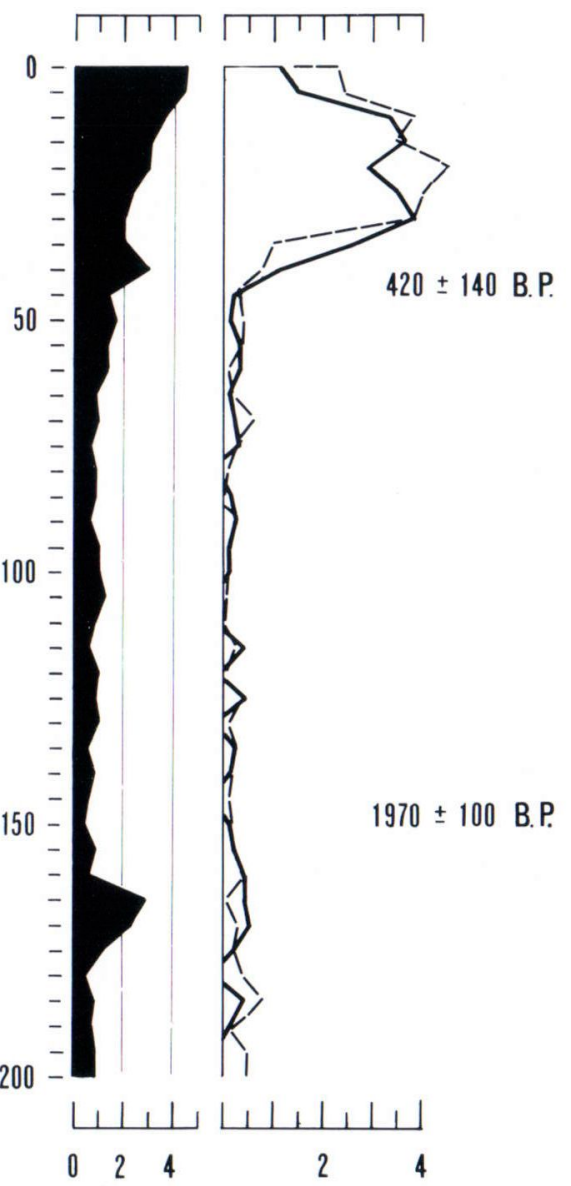

Ash-content Cerealia \%o AP+NAP

Fig. 1. A correlation between the ash content values and those of the Cerealia and weed pollen (Artemisia, Chenopodiaceae, Plantago and Rumex) in the Sphagnum peat profiles of Retulansuo, Lemunsuo and Loimansuo dated by $\mathrm{C}^{14}$ methods. 


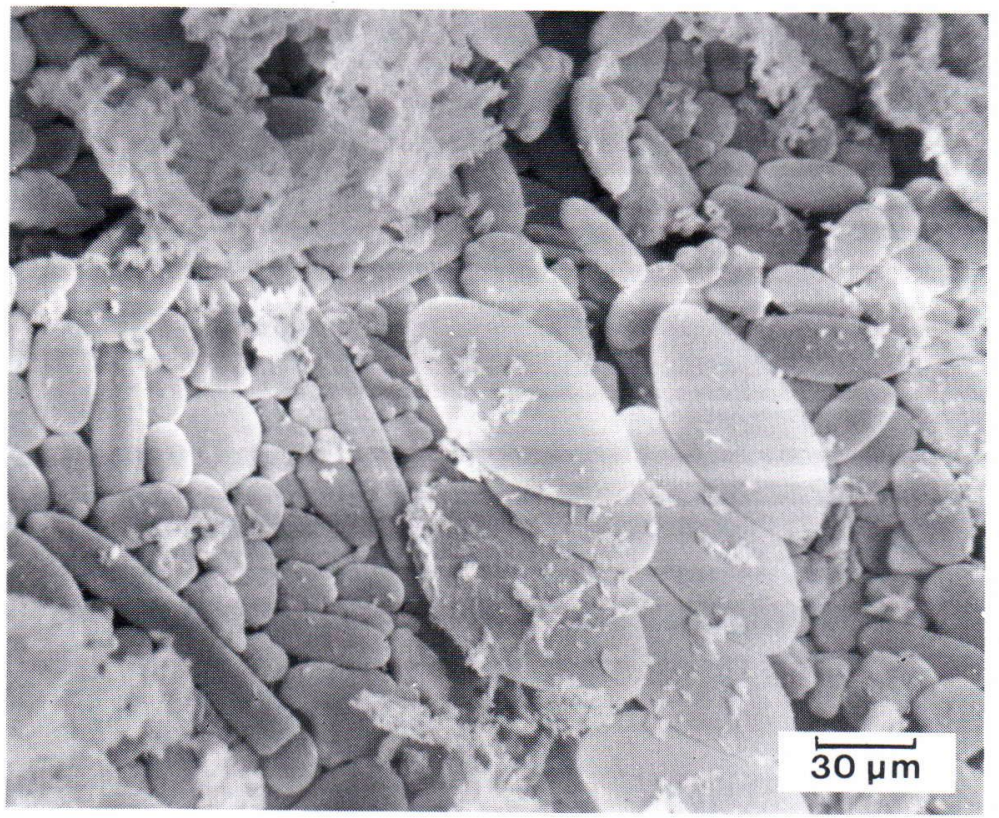

Fig. 2. Inorganic remains of the microflora found among the ignition residues of Sphagnum peat in Loimansuo at the $10-15 \mathrm{~cm}$ level. SEM, Viikki.

In all the diagrams, the surface layers show a discrepancy between the increasing ash content values and the decreasing Cerealia frequencies. In all these cases, however, vast modern fields with intensive agriculture are located close to the samples sites. This suggests that the ash content of peat deposits is an even more useful indicator of field cultivation (field erosion) than is Cerealia pollen, which is affected by varying amounts of pollen, depending on the crops cultivated. It is obvious that, the early predominance of Secale, for example, can be traced in the Cerealia curve but that the pollen values of Hordeum are considerably underestimated (cf. Vuorela 1973). The grade of tilling, the extent to which the land was worked and wind erosion do not substantially depend on the species cultivated. The same phenomenon is shown by the topmost samples of the curves for natural indicators of bare mineral soil, obviously as a result of the high grade of technology and the lack of weeds in modern agriculture. The maximum values for

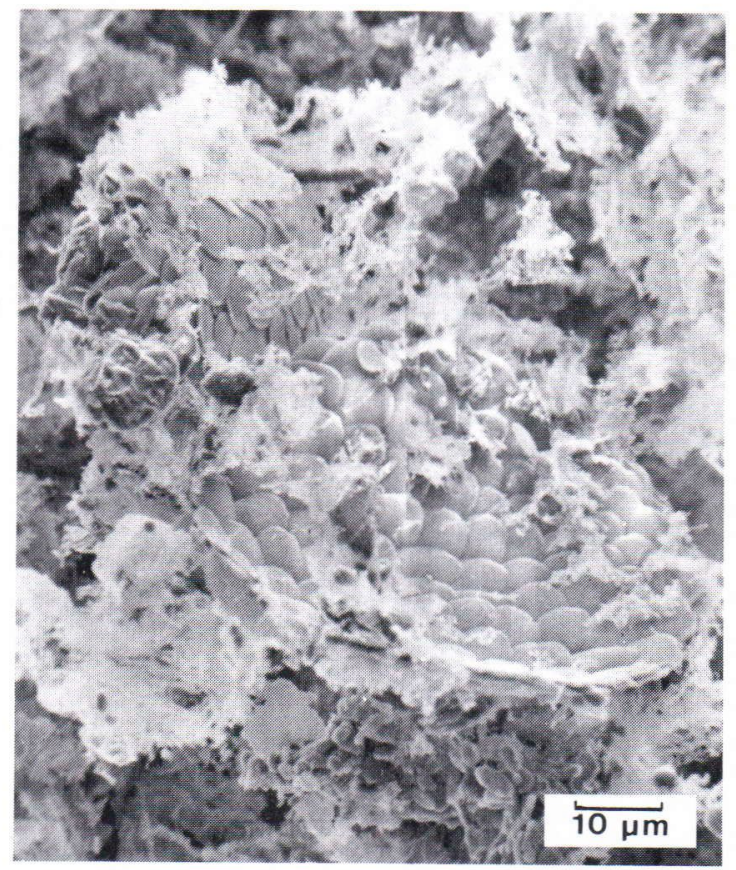

Fig. 3. Remains of Flagellata (Chrysophyta, Chrysomonadinae) Mallomonas sp. (acc. to Järnefelt et al. 1963), found in the ingnition residues of Sphagnum peat in Loimansuo at the $10-15 \mathrm{~cm}$ level. SEM, Viikki. 
these herbs occur at the pre- and interphases of the Cerealia maxima and indicate the presence of fallow land and probably grazing.

In addition to the raised bogs described above, the ash content values were determined from two cores of minerogenic Carex peat. The profile from Perkiö (Fig. 4), which does not include the recent peat deposits, shows that the mean values for the ash content in "clean» Carex peat are c. $5 \%$. Contamination by the underlying mineral soil brought about by earlier wave action and later biological activity (Anderssen 1979) increases these values towards the limnotelmatic horizon.

This sample site is located in the immediate vicinity of a Corded Ware dwelling site, dating back to 4000-4500 B.P. (Edgren 1970, Alhonen 1970). The role of agriculture in settlements of this period is still a moot point and resulted in thorough investigations at the dwelling site (Vuorela 1982) in the course

\section{PERKIÖ, Hauho}

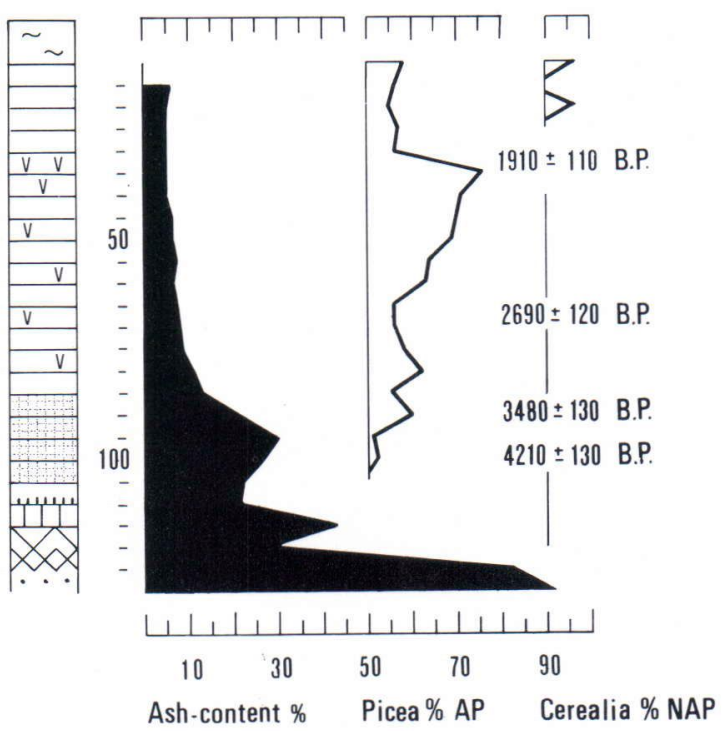

Fig. 4. The curves for the ash content values, Picea pollen and Cerealia in the Carex peat profile from Perkiö. The stratigraphical symbols are explained in the text. of which the ash content of the sample core was also analysed. At first sight, the conspicuous increase in the ash content at the 90-100 cm level seemed to indicate that the aeolian sand was redeposited from the dwelling site into the peat. Further examination demonstrated, however, that the anomalies in the ash content values were caused by considerable amounts of diatoms redeposited at this level and whose main species were the acidophilous Eunotia praerupta var inflata, Pinnularia viridis var. intermedia and Eunotia diodon. Several other Eunotia, Pinnularia and Nitzschia species were sporadically encountered (analysed by $\mathrm{H}$. Haila). It is interesting to note that yet one more pre-agrarian phase of local human influence - indicated in this diagram by the decline of Picea at the $60-80 \mathrm{~cm}$ level - is not reflected in the ash contents.

The stratigraphy of Vohtenkellarinsuo (Fig. 5) resembles that of Perkiö, consisting mainly of Carex peat with abundant fragments of wood. In this profile two layers of ash and carbonized wood indicate local deforestation by burning. Both horizons, that at the 5-7 cm level and that at the $45-$ $50 \mathrm{~cm}$ level, are manifested in the ash content values. The slight decrease in these values at the Carex/Sphagnum peat boundary at the $35 \mathrm{~cm}$ level can be attributed to a change in the rate of peat accumulation.

The ash contents of Carex peat (4-5\%) and of the Sphagnum peat affected by aeolian field erosion (3-4\%) correlate with the corresponding values in the previous diagrams. Likewise, the uppermost samples show a sharp increase in the ash value and a decrease in the Cerealia values.

\section{Conclusions}

The diagrams referred to above allow the following conclusions to be drawn: 
VOHTENKELLARINSUO, Paimio

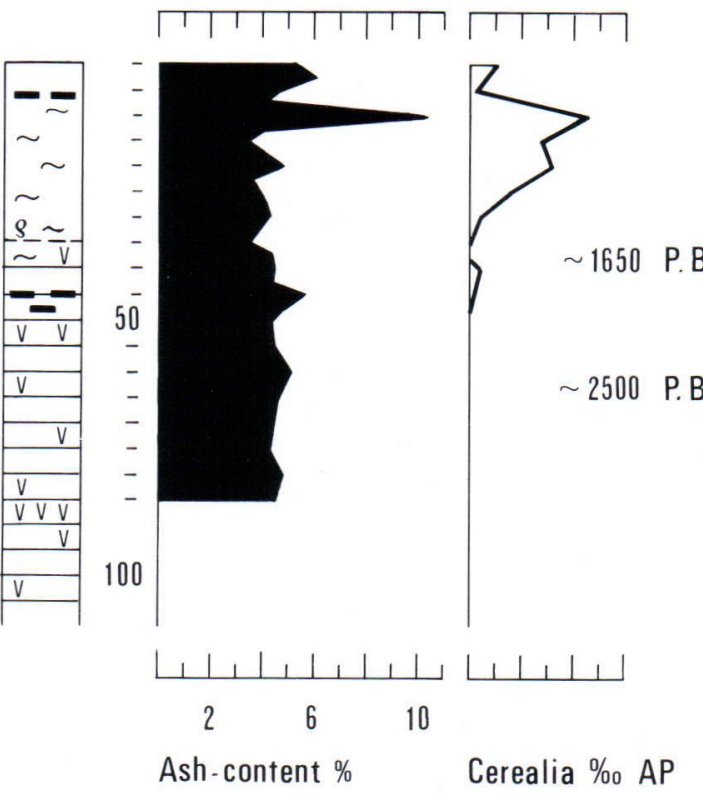

Fig. 5. A correlation between the ash content values and those of Cerealia pollen in the bog Vohtenkellarinsuo. The stratigraphical symbols are explained in the text.

Field erosion by wind affects the bare mineral soil surface in connection with settlement and field cultivation. This is recorded in fluctuations in the ash content values of the surrounding peat lands. The extent of field erosion may be determined by a careful loss-on-ignition analysis of Sphagnum peat carried out from the same material as pollen analysis. This faster method could sometimes be used as a preliminary elementary means of analysis to establish the main phases of local human activity in the profile.

The ash content of clean ombrogenous Sphagnum peat is c. $1 \%$. A marked increase to $2-3 \%$ is noted in connection with early agriculture, whereas the value of $5 \%$ reached in the uppermost layers only indicates recent field cultivation. The present material shows that the ash content of nonaffected Carex peat is c. $5 \%$. The difference between the ash values for Sphagnum and Carex peat could be attributed partly to the different rates of growth, because the component of aeolian material is compared with the pollen concentration values (cf. Kramm 1978), not forgetting, however, the genetical differencies between these two peat formations.

A regular discrepancy exists in the topmost low-humified peat layers between the increasing ash content values and the decreasing indicator and Cerealia frequencies. This may be due to the small amount of pollen in the recently predominant crops, Hordeum and Avena, as well as to the shortage of fallow fields. Since, however, neither the way nor the extent to which the land was worked nor wind erosion depend on the crops cultivated, the ash content may be considered as a more reliable indicator of field cultivation than the value of Cerealia. Depending on the quality of the mineral soil, the ash content of peat deposits may even act as an indicator of the distance between the sample site and the centre of activities of the settlement. Thus it could help in distinguishing the sporadic Cerealia pollen and other indicator pollen of primitive local slashand-burn cultivation from the pollen transported long distances.

In Carex peat the ash values increase towards the limnotelmatic contact of the profile. Close to that horizon the diatoms may occasionally affect the values and result in a misinterpretation. The silicoflagellates found in the ignition residues of the surface layers of Sphagnum peat occur in amounts too small to affect the ash values.

The dust-input in Sphagnum peat may be of some importance for the determination of bulk density values $\left(\mathrm{g} / \mathrm{dm}^{3}\right.$ ) as well (Karesniemi 1972). The loss-on-ignition values have then often been omitted merely because of the ombrogenous nature of Sphagnum (Tolonen 1977). The proportion of airborn 
mineral material in the surface layers of the peat deposits could have some influence on the estimation of peat production (Pakarinen \& Tolonen 1977).

With reference to the present material it seems likely that, in certain circumstances, the ash content of peat deposits may consist of inorganic material derived from the surroundings of the bog, and that as such, it may, together with the pollen flora, help us to reconstruct human activities in the past.

\section{References}

Aaby, B. \& Tauber, H., 1974. Rates of peat formation in relation to degree of humification and local environment, as shown by studies of a raised bog in Denmark. Boreas 4, 1-17.

Alhonen, P., 1967. Palaeolimnological investigations of three inland lakes in south-western Finland. Acta Bot. Fennica 76, 1-56.

-, 1970. En pollenanalytisk undersökning vid stenåldersboplatsen Perkiö i Hauho socken, södra Finland. SMYA-FFT 72, 113-118.

Anderssen, S.Th., 1979. Brown earth and podzol: soil genesis illuminated by microfossil analysis. Boreas 8, 59-73.

Auer, V., 1924. Die postglaziale Geschichte des Vanajavesisees. Comm. Inst. Quaest. Forest. Finl. 8, 1-156.

Driessen, P. M., Soepraptokardjo, M. \& Pons, L., 1979. Formation properties, reclamation and agricultural potential of Indonesian ombrogenous lowland peats. In: Proc. Int. Symp. Peat in Agriculture and Horticulture, Israel 1975. International Peat Society pp. 67-108.

Edgren, T., 1970. Studier över den snörkeramiska kulturens keramik i Finland. SMYA-FFT $72,1-118$.

Fries, M., 1951. Pollenanalytisk vittnesbörd om senkvartär vegetationsutveckling, särskilt i skogshistoria, i nordvästra Götaland. Acta Phytogeogr. Suec. 29, 1-220.

Glückert, G., 1976. Post-Glacial shore-level displacement of the Baltic in SW Finland. Ann. Acad. Sci. Fennicae A III (118), 1-92.

,- 1977. Itämeren rannansiirtymisestä Turussa ja sen lähiympäristössä. Publ. Departm. Quaternary Geology, Univ. Turku. 21, 1-36.

Iversen, J., 1941. Landnam i Danmarks Stenalder. En pollenanalytisk Undersögelse over det förste Landbrugs Indvirkning paa Vegetationsudviklingen. Danmarks Geol. Unders., II Raekke 66, 1-68.

,- 1949. The influence of prehistoric man on vegetation. Danmarks Geol. Unders., IV Raekke 3 (6), 1-25.

Järnefelt, H., Naulapää, A. \& Tikkanen, T., 1963. Planktonopas. Kalavesitutk. II. Suomen Kalastusyhd. julk. 34.133 p.

Karesniemi, K., 1972. Dependence of humification degree on certain properties of peat. Proc. 4th Int. Peat Congress Otaniemi, Finland, 2, $273-282$.

Kivinen, E. \& Pakarinen, P., 1981. Geographical distribution of peat resources and major peatland complex types in the world. Ann. Acad. Sci. Fennicae A III (132), 1-28.

Kramm, E., 1978. Pollenanalytische Hochmooruntersuchungen zur Floren- und Siedlungsgeschichte zwischen Ems und Hase. Abhandl. Landesmuseum f. Naturkunde, Münster. 40, $225-245$.

Moore, P. D. \& Bellamy, D. J., 1974. Peatlands. London. $221 \mathrm{pp}$.

Nieminen, P. 1979 Havainto piilevien lämmönkestävyydestä. Geologi 5, 88-90.

Nunez, M. \& Vuorela, I., 1979. A tentative evaluation of cultural pollen data in early agrarian development research. Suomen Museo 1978, $5-36$.

Pakarinen, P. \& Tolonen, K., 1977. Pintaturpeen kasvunopeudesta ja ajoittamisesta (On the growth-rate and dating of surface peat). Suo 28 , $19-24$.

Raikamo, E., 1982. Päijät-Hämeen suot ja turvevarojen käyttömahdollisuudet. Summary: The peatlands of Päijät-Häme and the potential use of their peat resources. Geol. Survey of Finland. Report of Investigation 57, 109 p.

Tolonen, K., 1977. Turvekertymistä ja turpeen tilavuuspainosta kolmessa etelä-suomalaisessa keidassuossa (On dry matter accumulation and bulk density values in three south Finnish raised bogs). Suo 28, 1-8. 
Tolonen, K., Siriäinen, A. \& Thompson, R., 1975. Prehistoric field erosion sediment in Lake Lojärvi, S. Finland and its palaeomagnetic dating. Ann. Bot. Fennici 12, 161-164.

Tolonen, K., Tolonen, M., Honkasalo, L., Lehtovaara, A., Sorsa, K. \& Sundberg K. 1976. Esihistoriallisen ja historiallisen maankäytön vaikutuksesta Lammin Lampellonjärven kehitykseen (The influence of prehistoric and historic land use on Lake Lampellonjärvi, South Finland). Luonnon Tutkija 80, 1-15.

Vuorela, I., 1973. Relative pollen rain around cultivated fields. Acta Bot. Fennica 102, 1-27.
-, 1975. Pollen analysis as a means of tracing settlement history in SW Finland. Acta Bot Fennica 104, 1-48.

-, 1982. Pollen stratigraphy and chemical analyses of a mineral soil profile at a Corded Ware dwelling site in Southern Finland compared with those of local organic sediments. PACT 7, 175-193.

-, 1983. Vohtenkellarinsuo, a bog in Paimio, SW Finland with a cultural origin. Bull. Geol. Soc. Finland 55, 57-66.

Manuscript received, November 4, 1982 